\title{
О ПРОБЛЕМНЫХ ВОПРОСАХ РЕГУЛИРОВАНИЯ РЫНКА ПРОФЕССИОНАЛЬНОЙ ЮРИДИЧЕСКОЙ ПОМОЩИ
}

\section{SOME PROBLEMATIC ISSUES \\ OF THE DRAFT CONCEPT \\ OF REGULATION OF THE PROFESSIONAL LEGAL AID MARKET}

\section{O. Ryabova \\ E. Tsvetkova}

Summary. This article is devoted to the consideration of issues related to the implementation of the draft Concept of regulation of the market of professional legal assistance in the Russian Federation. The authors point to the need for reformatory changes envisaged by the draft and the importance of consolidating all entities providing legal assistance and legal services in the Russian Federation as a possibility of creating a single institution for providing qualified legal assistance as part of the bar. However, there are a number of problems associated with some misunderstanding by the developers of the named Concept of the essence of advocacy. The main issue under study is the problem of differentiation of the concepts of "legal aid" and "legal service". It is noted that with this approach, the effective implementation of this project is impossible.

Keywords: concept. advocacy, advocacy, association, monopoly, legal aid, legal service.

И нститут адвокатуры в любом государстве является символом защиты прав и свобод граждан. Адвокатура наравне с правоохранительными органами, прокуратурой и судом должна стоять на страже интересов и прав физических и юридических лиц. Такая позиция представляется единственно правильной с точки зрения правового и демократического государства, с учетом того, что адвокатура является частью правовой системы России, а законодательство указывает, что адвокат, учитывая положения Федерального Закона от 31.05.2002 № 63 - Ф3 «Об адвокатской деятельности и адвокатуре в Российской Федерации» (далее Закон об адвокатуре) является независимым советником по правовым вопросам. Не лишним будет отметить также, что адвокат является единственным представителем юридического сообщества, осуществляющего правовую помощь, который действует на основании специального правового статуса, приобретенного в соответствии с российским законодательством об адвокатуре.

\author{
Рябова Ольга Алексеевна \\ Преподаватель, ФКОУ ВО «Владимирский \\ юридический институт ФСИН России» \\ frau.lelya2012@yandex.ru \\ Цветкова Елена Владимировна \\ К.ю.н., дочент, Владимирский государственный \\ университет имени Александра Григорьевича \\ и Николая Григорьевича Столетовых \\ cvetcova-e@mail.ru
}

Аннотация. Настоящая статья посвящена рассмотрению вопросов, связанных с реализацией проекта Концепции регулирования рынка профессиональной юридической помощи в РФ. Авторы указывают на необходимость реформаторских изменений, предусмотренных проектом, и важность консолидации всех субъектов, оказывающих юридическую помощь и юридические услуги в РФ, как возможности создания единого института оказания квалифицированной юридической помощи в составе адвокатуры. Однако определяют ряд проблем, связанных с некоторым непониманием разработчиками названной Концепции сущности адвокатской деятельности. Основным исследуемым вопросом является проблема дифференциации понятий «юридическая помощь» и «юридическая услуга». Отмечается, что при таком подходе эффективная реализация данного проекта невозможна.

Ключевые слова: концепция. адвокатура, адвокатская деятельность, объединение, монополия, юридическая помощь, юридическая услуга.

В 2017 году Министерством юстиции был представлен и опубликован Проект Концепции регулирования рынка профессиональной юридической помощи (далее Концепция). Предполагается, что настоящий документ, в случае его утверждения, начнет процесс реформирования оказания юридической помощи в России путем консолидации лиц, которые имеют отношение к процессу оказания правовой помощи физическим и юридическим лицам в рамках адвокатского сообщества.

Основной доктриной данной Концепции, в случае ее реализации, является то, что практикующие юристы не смогут оказывать юридическую помощь, не имея статуса адвоката. Причем, необходимо отметить, что речь идет обо всем спектре такой помощи, включая консультирование, анализ и составление правовых документов, представительство, участие в судебных процессах, которые имеют место в процессуальном праве России. Результатом такой трансформации должен стать сильный институт адвокатуры, который будет 
почти абсолютным монополистом по оказанию юридической помощи на территории РФ.

Безусловно, предложенный процесс становления и реализации Концепции, с точки зрения вовлечения в нее человеческого ресурса, предлагающего свою помощь на юридическом поприще, предполагается осуществить максимально «мягко» для участников реформы и во временной промежуток, имеющий реальные очертания для процесса становления и адаптации правовой конструкции, о которой идет речь. Сама идея является прекрасной возможностью, чтобы сформировать в российском правовом поле здоровый сильный институт адвокатуры. Тот факт, что для закрепления результатов к моменту полной реализации реформаторских замыслов, необходимо принять обновленное законодательство, регулирующее адвокатуру и адвокатскую деятельность, не только не должен вызывать сомнений и вопросов, но и являться неотъемлемым условием реализации Концепции. В противном случае все труды будут напрасными, так как определенная часть нынешних норм, регулирующих деятельность института адвокатуры, устарела и требует изменений уже на настоящий момент времени.

Однако реформа в рамках указанной Концепции, на наш взгляд, не получила должной поддержки среди практикующих юристов, не имеющих статуса адвоката, даже, учитывая предлагаемую облегченную процедуру наделения желающих статусом адвоката, при условии их соответствия требованиям и вектору, предложенному законодателем. [4] Также не встретила она понимания у ряда представителей юридической профессии, адвокатов и части лиц, являющихся адресатами получения юридической помощи.

Полагаем, что такая ситуация связана не только с субъективным отношением каждого, не имеющего статуса адвоката, практикующего юриста, вероятно, не желающего связывать себя корпоративными правилами адвокатского сообщества, а также скептического отношения к указанной реформе иных лиц.

На наш взгляд, авторы Концепции не уделили должного внимания одному из основополагающих моментов, а именно тому, что адвокат оказывает именно юридическую (правовую) помощь - в данном случае суть не зависит от словесной интерпретации. А ведь эта мысль «красной нитью» проходит через всю историю становления российской адвокатуры, найдя свое отражение в Законе об адвокатуре, определяя адвоката как независимого советника по правовым вопросам. Остальные же представители юридического сообщества, имеющие отношение к практической деятельности в области права оказывают юридические услуги.
От этого, в том числе, необходимо отталкиваться при создании монополии адвокатов на рынке профессиональной юридической помощи. Институт адвокатуры, встроенный в правовую систему РФ, должен иметь равный уровень правового статуса по сравнению с остальными субъектами данной системы, к которым мы можем отнести правоохранительные органы, прокуратуру, суд и некоторые другие. Только в этом случае истинная суть и значимость профессиональной юридической помощи, которая будет оказываться исключительно адвокатом, будет правильно понята и воспринята обществом.

Применение к оказанию адвокатом правовой помощи терминологии «оказание юридической услуги» претит сути адвокатской деятельности, девальвируя ее статус и значение. Мы не можем представить применения подобной терминологии в отношении иных субъектов правовой системы России - оказание судом юридических услуг по отправлению правосудия или оказание юридических услуг органами следствия по расследованию уголовного дела, звучит противоестественно. Потому, что нельзя предназначение и деятельность вышеуказанных органов в области права рассматривать как услугу. Их деятельность предполагает защиту прав и интересов граждан и юридических лиц в случаях, когда, права последних нарушены и такую защиту в лице вышеуказанных органов государство осуществляет не в рамках оказания услуги, а в рамках естественного цивилизованного процесса защиты в соответствии с Конституцией РФ. В противном случае государство перестало бы отвечать принципам правового и демократического. Такое же отношение следует применять и к оказанию адвокатами профессиональной юридической помощи в рамках защиты конституционных прав и интересов граждан и юридических лиц.

Если мы обратимся к нормам права, то увидим, что адвокатская деятельность не является предпринимательской.[2] Также Закон об адвокатуре не относит к адвокатской деятельности юридическую помощь, которая оказывается работниками юридических служб юридических лиц, работниками государственных органов, участников и работников организаций, оказывающих юридические услуги, индивидуальных предпринимателей, нотариусов и патентных поверенных, [2] Таким образом, законодатель дистанцировал адвокатскую деятельность от оказания юридических услуг, подчеркивая указанными нормами, что весь предел адвокатской деятельности относится исключительно к квалифицированной юридической помощи. Это одно из основных отличий адвоката от иного лица, оказывающего юридическую помощь в рамках юридических услуг.

Помня о вышесказанном, важно отметить также, что именно адвокат, осуществляя квалифицированную юри- 
дическую помощь, не только обладает исключительными правами, но и несет обязанности, регламентированные в Законе об адвокатуре. У адвоката наличествует ответственность за не оказанную или некачественно оказанную помощь. Если мы обратимся к лицам, оказывающим юридические услуги, то оказание ими юридической помощи не регламентируется не одним специальным законодательным актом, а лишь общими нормами. То же самое можно сказать и об ответственности, То есть рынок юридических услуг не урегулирован законодательно, а адвокатская деятельность имеет строго очерченные границы, правовое регулирование, персональную ответственность адвоката. Безусловной гарантией сохранения конфиденциальности информации в работе адвоката является институт адвокатской тайны.[2] Здесь же стоит упомянуть о профессиональной этике, которая установлена в адвокатском сообществе. Кодекс профессиональной этики обязателен к исполнению каждым адвокатом РФ. Это те основополагающие начала, которые дают нам возможность считать адвоката исключительным субъектом в сфере юридической помощи.

Однако Концепция приравняла профессиональную юридическую помощь адвоката к юридическим услугам, указав что одной из двух групп сектора юридических услуг являются адвокаты.[4] Полагаем, что такая позиция ошибочна. В этом смысле совершенно согласны с Е.В. Астаповой, которая отмечает, что авторы Концепции смешали два разных понятия - «юридическая помощь» и «юридические услуги», фактически отождествив их. [5]

В свете доктринальной идеи Концепции, необходимо обозначить не только намерение объединить юристов, оказывающих юридическую помощь, в составе адвокатского сообщества, но и определить, что адвокат - это полноправный представитель правовой системы РФ, оказывающий профессиональную квалифицированную юридическую помощь. Такой подход даст возможность обществу понять и принять эту Концепцию как единственно правильную и необходимую для качественного и профессионального осуществления защиты прав и свобод, указанных в Конституции.[1] Однако, мы полагаем, что для реализации Концепции необходимо внести в нее определенные корректировки и поправки относительно разграничения понятий «юридическая помощь» и «юридические услуги», а также в те положения, которые прямо или косвенно обна- руживают некое несоответствие принципам адвокатской деятельности и адвокатуры.

Адвокатура должна остаться независимым институтом, сохраняющим здоровый баланс во взаимоотношениях участников с государственными органами. Осторожность, с которой реагируют на Концепцию действующие адвокаты, оправданна. Некоторые положения вызывают вопросы и споры. Причем, по нашему мнению, они напрямую связаны с отсутствием в Концепции разграничения между «юридической помощью» и " юридической услугой». Иными словами, что хорошо для юридических услуг, то неприемлемо при оказании юридической помощи в контексте адвокатской деятельности. Примером может являться предлагаемая норма о найме адвокатов адвокатами на работу по трудовому договору.[4] Это, на наш взгляд, полностью противоречит принципу независимости адвоката и, пожалуй, никакие поправки, не смогут это противоречие убрать. Концепция содержит еще ряд подобных предложений, необходимость реализации которых весьма сомнительна и вызывает вопросы. В противном случае, подобная коммерциализация адвокатуры может привести к разрушению этого института. Повторимся, указав, что суть деятельности адвоката заключается в профессиональной юридической помощи в защите прав и свобод граждан и юридических лиц в РФ. И тот факт, что помощь адвокатов осуществляется за плату в виде гонорара, не меняет ее сути. Законодательством предусмотрено и оказание бесплатной юридической помощи, в том числе и адвокатами.

Подводя итог вышесказанному, следует признать, что идея консолидации лиц, оказывающих юридическую помощь, в рамках единого профессионального сообщества, которым является адвокатура, видится своевременной и актуальной. Однако, для успешной реализации Концепции считаем необходимым вернуться к ее доработке и привести ее положения в соответствие с современными требованиями предъявляемыми к пониманию, деятельности и взаимодействию правовых институтов, а также базовыми принципами оказания адвокатами профессиональной юридической помощи, основанными на многолетнем опыте становления института защиты и положений Закона об адвокатуре. Только в этом случае будут достигнуты понимание указанной идеи и целей, на решение которых направлена ее реализация.

\section{ЛИТЕРАТУРА}

1. Конституция Российской Федерации (принята всенародным голосованием 12 декабря 1993 года) // Российская газета. № 23725.12 .1993 г.

2. Федеральный Закон от 31.05.2002 № 63 - Ф3 «06 адвокатской деятельности и адвокатуре в Российской Федерации (в ред. от 29.07.2017) // Российская газета. № 100 05.06.2002. 
3. Постановление Правительства РФ от 15.04.2014 № 312 (ред. от 31.03.2017) «06 утверждении государственной программы Российской Федерации «Юстиция» // Собрание законодательства РФ. 2014. № 18 (часть ІІ). Ст. 2158

4. Проект Концепции регулирования рынка профессиональной юридической помощи // официальный сайт Министерства юстиции PФ (URL: http:// minjust.ru/ru/deyatelnost-v-sfere-advokatury/koncepciya-regulirovaniya-rynkaprofessionalnoyyuridicheskoy (дата обращения: 12.08.2018); на момент подготовки материала соответствующая страница удалена.

5. Астапова Е.В. К вопросу о Концепции регулирования рынка профессиональной юридической помощи и проблемах ее реализации. // Юристь — Правоведъ, № 3, 2018 г. стр. 106-113

๑ Рябова Ольга Алексеевна ( frau.lelya2012@yandex.ru ), Цветкова Елена Владимировна ( cvetcova-e@mail.ru ).

Журнал «Современная наука: актуальные проблемы теории и практики»

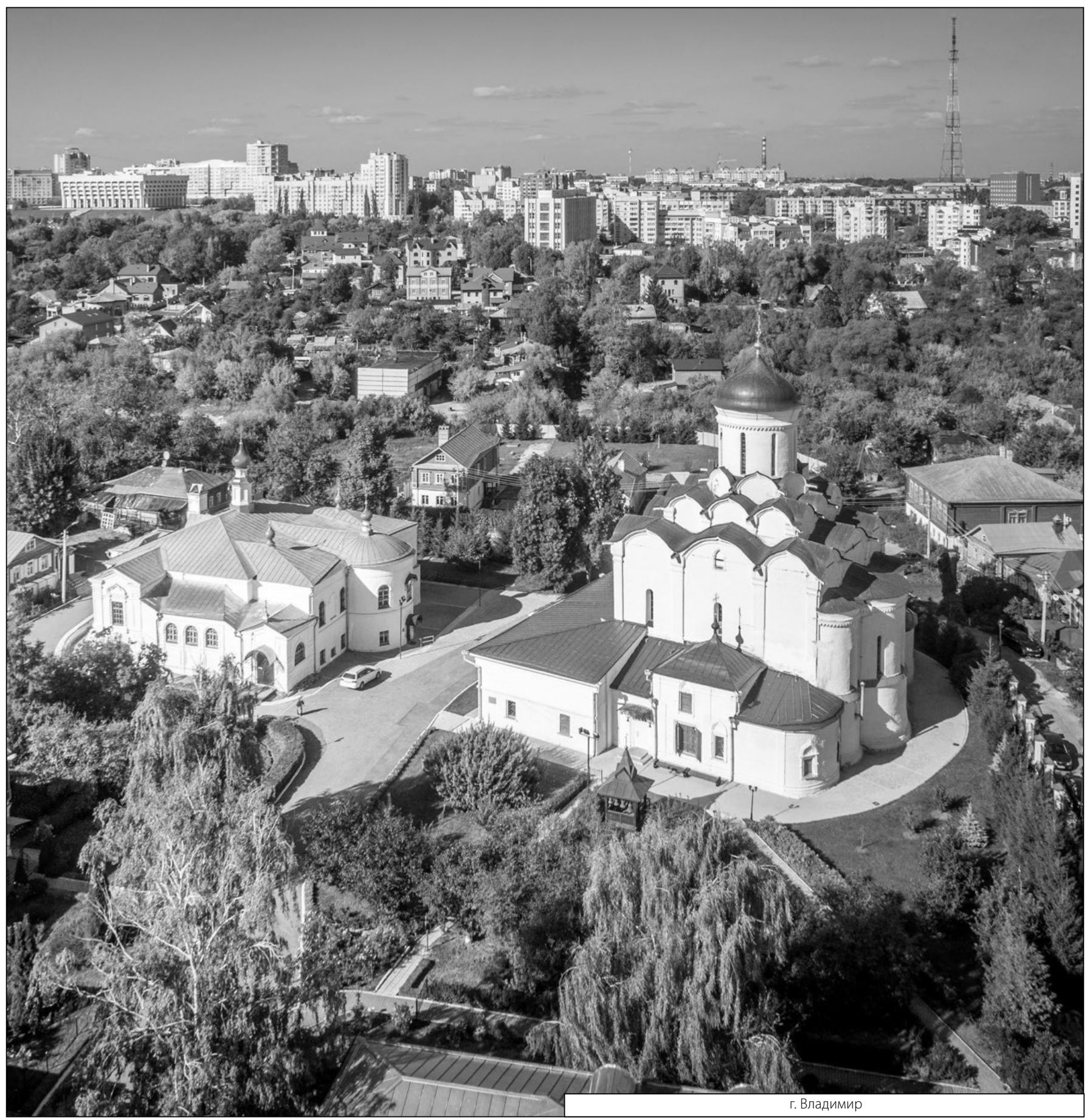

